\title{
Leaders and leadership in a climate of uncertainty
}

DOI:

$10.1177 / 1741143217707522$

\section{Document Version}

Accepted author manuscript

Link to publication record in Manchester Research Explorer

\section{Citation for published version (APA):}

Rayner, S. M. (2018). Leaders and leadership in a climate of uncertainty: a case study of structural change in England. Educational Management Administration and Leadership, 46(5). https://doi.org/10.1177/1741143217707522

\section{Published in:}

Educational Management Administration and Leadership

\section{Citing this paper}

Please note that where the full-text provided on Manchester Research Explorer is the Author Accepted Manuscript or Proof version this may differ from the final Published version. If citing, it is advised that you check and use the publisher's definitive version.

\section{General rights}

Copyright and moral rights for the publications made accessible in the Research Explorer are retained by the authors and/or other copyright owners and it is a condition of accessing publications that users recognise and abide by the legal requirements associated with these rights.

\section{Takedown policy}

If you believe that this document breaches copyright please refer to the University of Manchester's Takedown Procedures [http://man.ac.uk/04Y6Bo] or contact uml.scholarlycommunications@manchester.ac.uk providing relevant details, so we can investigate your claim.

\section{OPEN ACCESS}




\title{
Leaders and leadership in a climate of uncertainty: a case study of structural change in England
}

\begin{abstract}
The research reported in this article contributes new understanding of leadership in the context of change, by investigating how the views, values and professional practices of those in leadership roles were revealed, interplayed and changed during a period of turbulence in a school in England. The governors of the school proposed changing the school's legal status from a local-authority school to an academy, which is an independent school funded by the State but governed and managed by an Academy Trust. In the current work on structural change affecting schools in England, there has been little real-time study of what it is like to be both a policy actor and a policy subject during a period of turbulence. In this article, which reports on events over a period of eighteen months, I explore the actions and perceptions of three actors in leadership roles. I examine their engagement in local agenda-setting and decision-making, including its implications for their values, identity and professional practice. The research reported in this article illustrates that, however confidently structural change is announced and promoted by policy-makers, its enactment may be problematic and inconclusive.
\end{abstract}

\section{Key words}

academies, academisation, school leadership, values

\section{Introduction}

This article reports on a study of how a school in England reviewed and changed its legal status in the context of government policy imperatives, including the commitment to convert schools into academies. I analyse the agenda-setting and decision-making that took place during a period of over eighteen months (January 2014 - September 2015), investigating the engagement and the views of those in leadership positions who were responsible for and affected by those decisions. I use this study of one school, St Clement's (pseudonym), to illuminate a political context in which radical 
moves are being made to re-shape the public education service in England as a market. Of all the policies that have contributed to this process, it is academisation that has been the most prominent and that has provided a political vehicle for the most significant systemic changes. I use the term academisation to refer to the process whereby a school in England changes its legal status, so that it is no longer maintained by its local authority, but by an Academy Trust, which is a company that has charitable status and that holds control over the land and other assets of the school. The name of the school is usually, but not necessarily, changed to include the word Academy.

The single school has featured in previous scholarship examining policy enactment, for example Ball (1981), Maguire et al (2001), Gewirtz (2002), McGinity and Gunter (2012), Maguire et al (2015). Much research into the implementation of the academies policy in England, however, has been written retrospectively (for example National College, 2010; Elliott, 2011), by those closely involved in the academisation process and having a stake in its success: principals and senior leaders (Macaulay, 2008; Daniels, 2011), governors (Elliott, 2011), or commissioned researchers (Pike, 2010; see also Bragg et al, 2011). A further group of empirical studies has investigated local campaigns of opposition to academies and academisation. That opposition might be prompted by a principled objection to privatisation, scepticism about the educational expertise of sponsors, potential changes to a school's character, or questions of equity due to the disruption of coherent local provision (Hatcher and Jones, 2006; Hatcher, 2009). The research reported in this article is not a story of success - a school transformed by becoming an 
academy under visionary leadership - or of failure - a school saved from becoming an academy because school leaders mobilised a campaign of principled or pragmatic resistance. The contribution is, rather, to show how those in leadership positions respond to the contradictions and complexities that accompany systemic change. I shall show how, against an unstable political background, school leaders develop institutional narratives in order to manage change, and how they articulate their understanding of its implications for their professional identity.

This study is distinctive in three ways. First, the data-generation timetable was synchronous with the decision-making process: both lasted from January 2014 to July 2015. Second, by interviewing participants at different stages, it was possible to explore uncertainties about what might happen, as well as views on what was happening, and to report on how actors' views changed over time. Third, the research is set in the context of academisation, the largest-scale systemic change in public education in England for fifty years. The enactment of academisation poses unprecedented operational challenges and value conflicts for those who hold leadership responsibilities in schools. I therefore begin by outlining the history and most significant features of academisation.

\section{Macro- and micro-politics}

The formation, in May 2010, of the Conservative/Liberal-Democrat Coalition government in the UK led to a rapid expansion of the number of academies in England and an increased urgency on the part of policy-makers to encourage, 
or compel, schools to become academies. Previous Labour governments (1997-2010) had explained the purpose of academies as being to replace failing schools in urban areas with new ones (DfES 2001, 2004, 2005; DCSF 2009). The Coalition government (2010-2015) adopted and adapted the academy model in order to further its objective of establishing a school system that was competitive, marketised and outside local-authority (LA) control (DFE 2010, 2015a, 2016). Policy discourses in support of the expansion of the academies programme continued to feature the language of 'freedom' and 'innovation' that had been employed by the previous Labour administration. They now also created a narrative in which the UK was falling behind other countries because its education provision was deficient:

It is only through (such) whole-system reform that education can be transformed to make our nation one of the world's top performers (Gove, 2010: np).

Academies were constructed as schools that were accorded greater autonomy by being rescued from bureaucratic control, outmoded practices and domination by vested interests such as teacher unions and local councils (Gunter and McGinity, 2014; Francis, 2015). Responsibility for the commissioning and provision of schooling was being taken away from local government, even though it retained its statutory responsibility to find a school place for every child.

A school that was about to begin the process of academisation was a suitable site to examine policy discourse and enactment during a period of structural change. Of the twenty secondary schools in its LA, in early 2014 St Clement's was one of only five that were not academies. It was a Church of England 
(CofE) school, maintained by the LA (its formal status being Voluntary-

Controlled), but with close links to its Diocese. In January 2014, the governors and Head Teacher (principal) of St Clement's set a new agenda for the school community by consulting on converting the school to academy status. The discussions associated with that consultation continued for eighteen months. Towards the end of that period, the academisation proposal was dropped following a series of meetings involving the school leadership and staff, the CofE Diocese, the LA, and governors and staff of potential partner schools. Consultation then began on a new proposal: that St Clement's should change its governance arrangements to become a Voluntary-Aided CofE school. That formal status had been available to schools since the 1944 Education Act. By July 2015 , this proposal had secured the support of staff and parents and had been approved by the LA.

\section{The study}

In this article, I draw on research conducted as part of the Academisation Study in Schools (AcSiS) doctoral project, whose overarching aim is to contribute through fieldwork studies to knowledge of academisation as a dynamic process of change. I explore the actions and views of three main actors in leadership roles at St Clement's: Martin, the Head Teacher; Carol, the Deputy Head Teacher; and Lesley, the head of a large subject department. All names are pseudonyms. Of the twenty participants in the overall study, I chose these three as a purposive sample (Cohen et al, 2011: 156-157) of those holding significant leadership responsibilities in the school. Here I acknowledge the example of Maguire et al (2001), by focusing on key 
actors in order to investigate the complexities and uncertainties of educational change. As well as exemplifying the actions and responses of leaders at different levels in the organisation - Head Teacher, senior leader and middle leader - Martin, Carol and Lesley typify the range of thinking of the staff as a whole, as revealed during the full programme of meetings and interviews. Each was interviewed at different stages during the study, allowing time for them to reflect and for their views possibly to change, as discussions progressed and as they became more aware of the fluid political context and its implications for their school. Because they were first interviewed in the months leading up to the 2015 UK General Election and then again immediately after that election, participants referred frequently to the education policies and discourses of the political parties. As I have explained, the position of the school and its governors also changed. The proposal to convert the school to academy status was dropped, for several reasons: difficulties in setting up a formal partnership (a Multi-Academy Trust (MAT)) with the partner primary schools, a financial risk-assessment, the position taken by the CofE Diocese and the position taken by the LA. By the time of the final interviews, all the staff knew that the school would not become an academy in the foreseeable future.

Three questions were used to structure the interviews:

1. In relation to the proposal for (St Clement's) to become an academy, what do you know of the current position in terms of national policy and the local context?

2. How are major decisions made and communicated in this school? 
3. What are your personal views about any possible changes, including their implications for your professional career, any political views that you might have, and how they might affect the values by which this school operates?

These questions shaped the agenda for more than thirty semi-structured interviews with governors, leaders, teachers and associate staff at St Clement's over a period of eighteen months. They encouraged participants drawn from all parts of the school to reflect on how they were positioned, literally and figuratively, in relation to the proposals to change the governance arrangements of their school.

\section{Reflecting on professional values in a climate of uncertainty}

I shall begin this section by examining interviewees' views on the national policy of academisation. I shall then explore aspects of structural change that are both specific to the context of St Clement's and illustrative of the wider picture of State-funded education in England. I shall argue that Martin, Carol and Lesley are representative of the range of views, positions and professional dilemmas that confront school leaders in England at this time of change.

\section{National policy}

Carol, Lesley and Martin all stated - as did all the staff whom I interviewed that the quality of educational provision nationally was being harmed by continual politically motivated change. That damage would be reduced, they said, if policy were in the hands of educators rather than politicians. Lesley 
was the most outspoken about this. Politicians had 'a constant need to interfere in education' (Lesley, interview 1), reiterated following the General Election:

Nick Clegg ${ }^{1}$ came out and said that (policy should be made by educators). Unfortunately, he was never going to be able to affect anything, but he actually said that they supported that. It was the only party that did (Lesley, interview 2).

The interviewees' unanimity did not relate to academisation per se, but to the uncertainty resulting from constant policy change. On academisation, their views differed. Carol saw the policy and change process as welcome and necessary, saying that St Clement's was on 'a journey hopefully to become an academy', because it would give the school the autonomy to make local decisions:

We have the best interests of the students at heart and that's ultimately who we're here to serve, and we know on a daily basis that when we want to invest money in the school and the curriculum, we just haven't got the freedom or the capacity to do it (Carol, interview 1).

Carol had overcome her initial scepticism and no longer believed the negative publicity that had been given to academies:

Initially, when the whole academy process first came out, you listen to what the media say about it, you don't have all the information there to make a well-informed judgment, and I think I did fall prey to a bit of the propaganda. As l've understood more about academies, what they stand for, how the processes will change, yes, there will be an extra level of governance. But it's the benefit of what it's going to bring to the school and the community (Carol, interview 1 ).

A year later, Carol was disappointed that the turn of events meant that the academy proposal could not proceed, but she still expected the school eventually to become an academy, with Voluntary-Aided status as a positive first step towards that objective. 
Lesley took a different view of the claims about localised autonomy:

Academisation? It comes from saying that the only reason that any school fails or any child fails is because there is not enough autonomy, that there's interference from local councils that might be Labour if it's the Tories, or might be Tories if it's Labour. That we have a political agenda within a school and it has to be a corporate agenda. And I just think it's based on an idea you can fix this by getting funding, make the kids do this, make the kids wear that, make the teachers work till five o'clock, teach them in threehour sessions ... no! I think it's just rubbish. Anyone can go in and get something out of kids if they just believe in them, have the right systems to monitor their progress and put the effort that they should do into their performance. And it doesn't come about better because $\mathrm{ICI}$ have sponsored you. You're not suddenly going to be a better teacher. And the kids' experience isn't suddenly going to be better because of that. What they need is an education that is suitable for them and personalised for them. Not all of this peripheral stuff and it infuriates me! What would fix it is all the political parties agreeing that education is taken out of politics and that we just look at what is the best, how are we going to get the highest standards, what works for our students. Not for a student in Japan or China or Sweden, but our students. And throwing corporate money at it isn't the way to do it (Lesley, interview 1).

Lesley had decided that she would not work for an academy and would resign if St Clement's became one:

I will not work for an academy, because it would be hypocritical of me, because I do not agree with the philosophy at all (Lesley, interview 1).

As Head Teacher, Martin managed a staff that included colleagues in leadership roles whose views ranged from those of Lesley to those of Carol. Martin had been opposed in principle to the Academies Programme, but he now saw it as irresistible. His view was that, as Head Teacher, he had a responsibility to make the inevitable structural change work to the benefit of pupils and staff. This would mean re-appraising his position within that broader political context:

I don't think local authorities will ever recover from what's been created nationally. Things have gone too far for that. So, if we are 
going to become an academy, I think what's incumbent upon myself as somebody leading an organisation is to look at a provider that would give equitable opportunities to staff, the best they possibly can for kids, and has a high degree of moral integrity (Martin, interview 1).

Martin's approach to the personal challenge of policy enactment in his school was not to represent or mediate policy, but to explain to staff what it would mean to them and the school. Through his words and actions, he sought to reassure them that the school, staff and pupils should suffer no harm and might even benefit from the change. In order to do so, he had to address the range of themes and concerns that I report and analyse in the rest of this section: the local context of St Clement's, including competition with other schools in the area; the recent history of the school; the challenges associated with external accountability; and the security and well-being of staff.

\section{Local context and competition}

In the first round of interviews for this study, only the Head Teacher and senior leaders referred to local competition. In the second interviews, almost all participants mentioned it. What had become widespread was the perception of a threat from the surrounding secondary schools, all of them academies, even though at that time none of them was oversubscribed or had better examination results than St Clement's. The main concerns related to marketing and finance:

I do worry about being a stand-alone school in an environment where there are lots of academy chains around us that might have bigger pulling power, bigger marketing power, and certainly we haven't got money for that (Martin, interview 1). 
There's an awful lot of competition in the area, and especially from the larger academy chains, where they are heavily focussed on marketing .... and I do think as a school we feel that pressure (Carol, interview 1).

In order to compete, three factors would be crucial: a reputation for high standards, made public in published inspection reports and performance tables; the ability to recruit the sort of pupils who would contribute to maintaining those outcomes; and a strong and distinctive brand to aid marketpositioning. Views on all three of these factors were influenced by the recent history of St Clement's.

\section{The school's history}

Academisation, as seen by the participants in this study, has two opposing forms, with different sets of consequences. For a school under scrutiny due to poor examination results or a low Ofsted ${ }^{2}$ rating, it is a threat. For a school with improving results and a good Ofsted rating, it is an opportunity. Staff at St Clement's recalled their previous experience of intervention instigated by Ofsted. Five years previously, the school had been on the point of being forced to convert to academy status after several years of poor examination results and critical inspection reports. An institutional narrative (Ball et al, 2012: 23) had developed at St Clement's, articulated by the senior leaders and echoed by the majority of the staff. Five years ago, so the narrative went, it had been a warm and caring school, recognised in its local area for its inclusive approach, where children were happy, safe and well-supported pastorally, although standards as represented by public examination results were low. The accommodation was inadequate, but everyone had become used to that and hardly noticed. The Head Teacher and senior leaders got on 
with running the school and teachers had a high degree of autonomy in their own classrooms. However, because outcomes were not improving year-onyear, the school had exposed itself to external intervention. Staff were beginning to fear that they were letting some of their pupils down by not challenging them to achieve better examination results. Carol recalled the time when intervention and forced academisation were thought to be imminent:

Panic went around the school: that's the easiest way I can describe it. At the time, it was when interviews were actually taking place for a Head Teacher and it left the school in a lot of uncertainty about who was going to take on that ultimate leadership role of the school. So, it was uncertainty, panic, and a lot of people thinking, you know, should they really be remaining in the school, we don't know whether we're coming or going at the moment (Carol, interview 1).

Following a move to a new campus and Martin's appointment as Head Teacher, examination results improved and Ofsted judged the school to be good. Now the institutional narrative was different. The school was increasing its appeal to families because of its new buildings, its improving results and its move into a different area. But it had to compete with other local schools, which were all academies. It was assumed that those academies must have generous marketing budgets, because staff saw their billboards as they drove to work and had heard that pupils were being provided with free uniforms. Academies could control their admissions policies, so the pupils that other schools did not want, particularly those with special educational needs, were being 'pushed towards us' (Martin), and the school was becoming a 'special needs sink-hole' (Lesley). The LA was suspected of being complicit in allowing academies to bypass admissions protocols. It also administered the 
contract with a private-sector company for managing and maintaining the new accommodation, and that contract was placing unsustainable financial pressures on St Clement's. Academy status was regarded as a potential means of escape from these problems. It was not just inevitable: it was the logical next step for the school. The contrast between forced and voluntary academisation, as perceived by the staff, was summed up by Carol:

I personally feel it's completely different. Everybody's more relaxed with the process (Carol, interview 2).

\section{External accountability}

Despite that logic and positivity, the inspection regime was seen as a continuing threat to the school, its leaders and staff. Without maintaining the Good Ofsted judgment, they said, St Clement's might revert to the insecurity and uncertainty of five years previously. That threat underpinned the need to maintain the school's reputation and market-position by controlling its recruitment of pupils and developing links with primary schools.

\section{Staff well-being}

Martin's responses throughout the research were influenced by his anxieties over the care, welfare and development of pupils and staff. Using a series of metaphors, he spoke of the responsibility that he felt, as a leader, to 'keep the wolves from the door', to help colleagues in 'a siege mentality, which is where education is at the moment', and 'to create a raft of stability' (Martin, interview 1). The main way in which Martin achieved this, as was confirmed by colleagues both in the senior team and throughout the school, was by 
communicating frequently and frankly about the course of events. It might be unsurprising that senior leaders should speak positively of this:

One of the lovely things about working with the Head is that he's always really open with the staff. Right from the word go when these talks were being held, in briefing he's there sharing the information. He's got that constant drip-feed to staff ... (Carol, interview 1)

- but that view was echoed by teaching staff and associate staff alike.

Consequently, when the original proposal for structural change was dropped, in favour of a change of status short of becoming an academy, staff saw no contradictions and no reason to lose confidence in the leadership. Both Carol, who favoured academisation, and Lesley, who opposed it, were persuaded by the rationale for the new plan:

We will be able to change the school to academy status in the future, I'm still hopeful on that. I think it would bring many advantages to the school (Carol, interview 2).

I see it as a side-step, protecting us from the vagaries of this government, if we become Voluntary-Aided (Lesley, interview 2).

These are the factors that influenced the thinking and positioning of the participants. In the next section, I shall analyse how they reflected on their identity as school leaders.

\section{Leaders, leading and leadership}

Carol expressed trust in, and loyalty to, her senior colleagues, especially Martin, even though her view of policy differed from his. She identified unquestioningly with the school senior leadership, speaking collectively of what the leadership team was seeking to achieve, expressing loyalty to Martin and distancing herself somewhat from the other staff: 
(Information) is shared with staff, but it depends if they're willing to listen or if they're actually paying attention when the information's shared (Carol, interview 1).

Although St Clement's was over-subscribed, Carol advocated a wide-ranging marketing approach:

Getting into local primary schools, supporting lessons, things we can do in-house rather than paying for publicised materials ...

You'd be a fool not to market the school. You can't just presume that one marketing strategy will keep the local population wanting to come to the school. You have to refresh your ideas because you don't know what other schools, local academy chains, are doing and offering (Carol, interview 2).

Carol reiterated her favourable view of academisation and her resistance to criticism of it. She referred in particular to her leadership responsibility for the professional development of staff:

There's so much bad publicity about academies. That's often the news that's circulated in social media and on the news, rather than looking at the good aspects and what academies can bring for schools: for finances, for recruitment of teachers but for long-term development of teachers as well, and you don't often hear about that aspect (Carol, interview 2).

Untroubled by doubts about government policy, Carol had a clear vision for the future of St Clement's as an academy. The delay over conversion was disappointing, but 'in the interim, I think Voluntary-Aided status is one way that we can go part of the way' (Carol, interview 2).

Lesley's loyalties were diverse and contradictory. While she was ideologically opposed to government policy, she trusted the Head Teacher who was implementing it, to the extent that, while on the one hand she was prepared to resign her post if St Clement's became an academy, on the other hand: 'if the head had gone "right, l'm going to start a Free School3", l'd have been there like a shot' (Lesley, interview 1). Having introduced herself as a 'middle 
leader', Lesley did not identify with the broader school leadership, even when major changes to the school - and to her personal circumstances - were being considered:

Obviously, the senior leadership team have a driving force and then they engage with the subject leaders where we're given a forum to comment. Discussion is sometimes pointless because it's actually a response to something outside the school, and those decisions are sort of forced on you in a way (Lesley, interview 1).

Lesley regarded her main commitment as a leader as being to her immediate colleagues in the subject team: she referred frequently to the curriculum in her subject, the ever-changing examination requirements, and the potential for interference from a policy-maker or MAT. She was worried about the teaching profession in general:

I'm really concerned about teachers' terms and conditions. I worry about the status of teachers. I worry about the constant denigration of the work that they do and the jobs that they do, and I do think ultimately the profession is being undermined and devalued (Lesley, interview 1).

From a personal point of view, Lesley's reflections on leadership led her to wonder what place she might have in an academised school system. More broadly, she felt a responsibility to speak out on behalf of the profession, despite her frustration that some colleagues did not see the need for protest:

A classroom teacher who doesn't see the implications of all of this on their teaching: I don't understand it.

(Interviewer: But they believe that the academies policy helps to raise standards: they're persuaded by the argument.) What argument? The argument is: you become an academy! Well I know that must be the case, because there are teachers who vote Conservative and who voted for their policies, so they have a different perspective on education than I do (Lesley, interview 2).

Throughout the discussions, it was clear that Martin saw steering the school through this uncertain time as a responsibility that depended almost entirely 
upon himself. He did not articulate that in an arrogant or heroic way - for example, he expressed no aspiration to be a 'system-leader' or CEO - but he believed that he was in a position to protect pupils and staff from what he saw as the risks of a corporatised agenda: a takeover by a profit-making organisation, threats to the employment rights of staff, restrictions on curriculum opportunities for vulnerable groups of children. He believed that he had an opportunity to safeguard the long-term future of St Clement's. Groups of people who might have contributed to that work were passive or remained in the background: his senior leadership team was in favour of academisation, there was little staff resistance to it, and the governors of the school had such confidence in his judgement and competence that they asked few questions about it. Martin talked continually of his worries:

The (government) agenda has infiltrated into systems that should be independent, like inspection (Martin, interview 1)

I can't see that we're ever going to go back to local authorities: there's been so much dismantling (Martin, interview 1)

I worry that two or three years down the line we will possibly be in a position where we can't put a budget together (Martin, interview 2)

The brutal styles of management (in academies), that I've read and heard about, are totally against what I believe gets the best out of people (Martin, interview 2)

It seems like the Conservative party are totally anti-inclusion, and I don't think there's a degree of support for kids with special needs, or an appreciation of what they need in terms of curriculum (Martin, interview 2).

Given the inevitability, as he saw it, of academisation, Martin assumed the responsibility of choosing a suitable MAT partner:

What I'm trying to do is look at a provider that will give people who may have professional reservations and concerns about academies the opportunity to see that this is the best of a bad bunch (Martin, interview 1) 
If we had a couple of years of duff results and I was removed and somebody was brought in, l'd have massive professional reservations about the way that the school could have gone. From a selfish point of view, with a degree of me having control of it, l've got no professional reservations at this moment because I think I can make it what I want to make it (Martin, interview 2).

\section{Discussion}

Of the twenty participants in this study, for this article I selected three to illustrate different aspects of, and approaches to, school leadership against the background of academisation. The course of events at St Clement's, and the response of participants to those events, reveals a more complex picture of leadership than is apparent in some existing literatures. This discussion applies new understanding to previous work on how school leaders develop institutional narratives in order to manage policy enactment (Ball et al, 2012; Coldron et al, 2014), on managing change in schools against a background of instability (Ouston, 1998) and on the restructuring of professional identity in a climate of neoliberalism (Beck and Young, 2005). It challenges the framing of school leaders as powerful change agents: 'system leaders' (Fullan, 2003; Hargreaves, D.H. 2010; Hargreaves, A. and Harris, 2011; Hargreaves, A., 2016).

In their research into policy enactment in secondary schools, Ball et al (2012) report on institutional narratives, constructed by school leaders, which are:

... both retrospective and prospective and work to 'hold things together' and 'move things on' and construct historical continuities or dramatic breaks with the past (52).

This is partly true of the narrative that emerged at St Clement's, but Martin's 
responses as a school leader exhibited further complexity. It was not a question of his translating, interpreting, or mediating policies, because he expressed reservations about so many of them: he had no enthusiasm for inter-school competition to recruit pupils, aggressive marketing, corporatisation (see Courtney, 2015b), private financing of education, being a 'system leader' supporting 'weaker' schools, or the marginalisation of LAs. Martin experienced and articulated more anxieties than any member of his staff, both because he understood more of the political complexities than they did and because of the overall responsibility that he bore. He exercised leadership by being open with colleagues, securing their confidence, influencing their thinking and positioning. As a result, he reached a consensus on what they all had little power to change. This resulted in a solution to the school's structural question that met no resistance, that 'held things together' and 'moved things on' (cf. Ball et al, 2012: 52). Martin was aware that this solution was a provisional one, because he was practising leadership in an unstable and non-rational context.

Ouston (1998) uses the term 'turbulence' to challenge the notion that change management is a rational process, set against a background of stability. This prompts two important questions for school leaders:

What is your understanding of the organisation that you work in?

Do you think that you are working in a rational professional world, where actions and outcomes are predictable? (Ouston, 1998: 122).

These paraphrase the questions that I explored in the interviews with Martin, Carol and Lesley. Their changed responses from one year to the next show the complex effects of turbulence. In 2014, all three immediately answered 
'yes' to the question 'do you think that this school will become an academy?'. In 2015, they all knew that the school would not, at least for the foreseeable future, become an academy: it would instead become Voluntary-Aided. They accepted this change of direction as a matter of course, showing little surprise, pleasure or disappointment at the turn of events. Their responses suggested that the potentially damaging effects of turbulence were mitigated by their trust in the integrity and expertise of those leading and managing the change (Ouston, 1998: 124); and also, perhaps, by their relief that someone was offering some clarity amid the uncertainty. This unanimous confidence enabled them to develop meanings for the change that satisfied their own values. Lesley and Martin, who had been opposed to academisation on principle, saw Voluntary-Aided status as a convenient alternative. Carol, who had been in favour of academisation, saw it as the first step along the route to the school becoming an academy, and one that afforded some of the freedoms that she sought for her school. Confidence in Martin's vision for the future of the school endured, even when the practical manifestation of that vision differed from his original articulation of it. The answer to Ouston's second question was clearly no: they were not working in a rational professional world, where actions and outcomes were predictable. However, whereas Ouston (1998) argues that turbulence provokes unpredictable behaviour, leading to lack of control or direction and damaging an organisation's processes and outcomes (p.123), at St Clement's, the reverse was the case. Martin practised leadership in a manner that, as all the staff agreed, was reliable and predictable, bringing stability amid the political turbulence. This aspect of successful educational leadership is little 
recognised in policy texts (for example DFE, 2015b) or research outputs (for example Leithwood et al, 2006) and is one of the conceptual contributions that emerge from this study.

Beck and Young (2005) discuss the challenges faced by professionals in a turbulent environment of political intervention, marketisation, performativity and state regulation. They identify a professional-identity crisis in the reaction of school practitioners to their changing environment, when cherished identities and commitments are undermined (p.184). They refer to three possible influences on professional identity that relate to this study: expertise, length of experience in the profession and differences between working in the private and the public sector. The findings from the broader AcSiS Project suggest that the influence of expertise and length of experience were negligible in this case. When participants articulated their causes for optimism or pessimism amid the uncertainty, what they said did not correlate with their seniority or the length of their professional experience. There was, however, a strong expectation that the school would adopt the practices of corporatised, private-sector organisations, with reduced democratic accountability to the local community. Here this study suggests an alternative view to that of Beck and Young, who see identity as something that can adapt and change without the criticism of compromise or submission. Carol's professional identity could adapt in response to structural change. For Carol, the knowledge that their school was operating in a market was a welcome challenge and an opportunity to secure its future, with structural change a necessary means to that end. The other two leaders in this study found structural change 
problematic and did not speak at all of marketing the school. Martin believed that if he could remain in his current leadership role, he could manage the employment of staff and meet the needs of current pupils as effectively in a privately governed school as in a LA one. His many anxieties, however, showed a realisation that some compromise and submission were necessary as he adapted his professional identity. Lesley simply refused to adapt and would leave the school if its governance arrangements changed.

Studies of leaders' engagement in, and responses to, structural change have typically been based on data generated retrospectively, exploring actors' reflections on what has occurred and what outcomes have resulted (National College, 2010; Pike, 2010; Daniels, 2011; Elliott, 2011). They have presented principals as system leaders, with the power to control and shape the future: 'School leaders must follow closely and be critical consumers of key developments in the bigger picture. This is not as difficult as it seems' (Fullan, 2003: 60; see also Hargreaves, D.H. 2010; Hargreaves, A. and Harris, 2011; Hargreaves, A., 2016). Such studies have shown that, while some of the legislative pressures affecting principals are particular to the national and local context, the trend towards increased competition, marketisation and 'choice' poses challenges and stresses that are evident on an international scale (Fullan, 2005; Bottery et al, 2008; 2013). Coldron et al (2014) have shown how, in England, head teachers may aspire to position themselves and their schools favourably in relation to other local schools (388), thereby 'shaping the local order' (391); but that the resulting 'prestige' may be 'precarious' (393). This article has moved that debate on by depicting leaders who are 
more preoccupied with those whom they lead than with the leaders that they themselves aspire to be. School leaders may adapt their positions, professional practice and identity, not in order to enhance their prestige - to which Martin, Carol and Lesley, for example, are indifferent - but to provide those whom they lead with an appearance of calmness and clarity amid political and operational turbulence. This study has both theoretical and methodological implications for future research. It suggests that there is a need to develop a more complex understanding of effective school leadership, by exploring the interplay between school culture, leaders' influence and professional identity. Further empirical studies should investigate the immediacy of leadership in action, when structural change has to be rationalised and explicated.

\section{Acknowledgements}

I should like to thank Helen Gunter, Steve Courtney and the anonymous reviewers for their comments on earlier versions of this article.

\section{Funding}

This research received no specific grant from any funding agency in the public, commercial or not-for-profit sectors.

\section{Disclosure statement}

No potential conflict of interest was reported by the author.

\section{Notes}

1. Nick Clegg was Leader of the Liberal Democrat Party from 2007-2015, Deputy Prime Minister in the Coalition government from 2010-2015, and no longer in office following the 2015 General Election. 
2. Ofsted (Office for Standards in Education, Children's Services and Skills) is a department of the UK government responsible for the inspection of State-funded schools in England. Schools in England are typically inspected by Ofsted every two or three years. Each aspect of the school is judged to be Outstanding, Good, Requiring Improvement or Inadequate.

3. A Free School is a type of academy: an independent, State-funded school, free to attend and not controlled by a local authority (see Courtney, 2015a).

\section{References}

Ball SJ (1981) Beachside Comprehensive: A Case-Study of Secondary Schooling. Cambridge: Cambridge University Press.

Ball SJ, Maguire M and Braun A (2012) How Schools do Policy: Policy enactments in secondary schools. London: Routledge.

Beck J and Young MFD (2005) The assault on the professions and the restructuring of academic and professional identities: a Bernsteinian analysis. British Journal of Sociology of Education, 26(2): 183-197.

Bottery M, Ngai G and Wong PH (2008) Leaders and Contexts: Comparing English and Hong Kong Perceptions of Educational Challenges, International Studies in Educational Administration, 36(1): 56-71.

Bottery M, Ngai G, Wong PM and Wong PH (2013) Values, Priorities and Responses: Comparing English Headteachers' and Hong Kong Principals' Perceptions of Their Work, School Leadership \& Management, 33(1): 43-60.

Bragg S, Allington D, Simmons K and Jones K (2011) Core values, education and research: a response to Mark Pike. Oxford Review of Education 37(4): 561-565.

Cohen L, Mannion L and Morrison K (2011) Research Methods in Education, Seventh Edition. London: Routledge.

Coldron J, Crawford M, Jones S and Simkins T (2014) The restructuring of schooling in England: The responses of well-positioned headteachers.

Educational Management Adminstration and Leadership 42(3): 387-403.

Courtney SJ (2015a) Mapping school types in England. Oxford Review of Education 41(6): 799-818.

Courtney SJ (2015b), Corporatised leadership in English schools. Journal of Educational Administration and History 47(3): 214-231. 
Daniels D (2011) From Reality to Vision: the 'Birth' of the Petchey Academy in Hackney. In: Gunter HM (ed.), The State and Education Policy. London: Continuum, 92-104.

DCSF (Department for Children, Schools and Families) (2009) A New Relationship with Schools. London: HMSO.

DfES (Department for Education and Skills) (2001) Schools Building on Success. London: HMSO.

DfES (Department for Education and Skills) (2004) Five Year Strategy for Children and Learners. London: HMSO.

DfES (Department for Education and Skills) (2005) Higher Standards, Better Schools for All. London: HMSO.

DFE (Department for Education) (2010) The Importance of Teaching. London: HMSO.

DFE (Department for Education) (2015a) Education and Adoption Bill. London: HMSO.

DFE (Department for Education) (2015b) National standards of excellence for headteachers. London: HMSO.

DFE (Department for Education) (2016) Educational Excellence Everywhere. London: HMSO.

Elliott J (2011) The Birth of Norwich's First School Academy: A Case Study. In: Gunter HM (ed.), The State and Education Policy. London: Continuum, pp. 52-65.

Francis B (2015) Impacting policy discourse? An analysis of discourses and rhetorical devices deployed in the case of the Academies Commission. Discourse: Studies in the Cultural Politics of Education 36(3): 437-451.

Fullan M (2003) The Moral Imperative of School Leadership. Thousand Oaks, NY: Corwin Press

Fullan M (2005) Leadership and Sustainability. New York, NY: Corwin Press

Gewirtz S (2002) The Managerial School. London: Routledge.

Gove M (2010) Major international study shows England's 15-year-olds performing poorly in mathematics, science and reading. Available at: www.gov.uk/government/news/major-international-study-shows-englands-15year-olds-performing-poorly-in-mathematics-science-and-reading (accessed 9 October 2016). 
Gunter HM and McGinity R (2014) The politics of the Academies Programme: natality and pluralism in education policy-making. Research Papers in Education 29(3): 300-314.

Hargreaves A and Harris A (2011) Performance beyond expectations. Nottingham: National College for School Leadership.

Hargreaves A (2016) Autonomy and Transparency: Two Good Ideas Gone Bad, in Evers, J. and Kneyber, R. (eds.), Flip the System: Changing

Education from the Ground Up. Abingdon: Routledge, pp. 120-133.

Hargreaves DH (2010) Creating a self-improving school system. Nottingham: National College for School Leadership.

Hatcher R and Jones K (2006) Researching resistance: campaigns against Academies in England. British Journal of Educational Studies 54(3): 329-351.

Hatcher R (2009) Setting up Academies, campaigning against them: An analysis of a contested policy process. Management in Education 23(3): 108112.

Leithwood K, Day C, Sammons P, Harris A and Hopkins D (2006) Seven strong claims about successful school leadership. Nottingham: National College for School Leadership.

Macaulay $\mathrm{H}$ (2008) Under the microscope, leading in a climate of close public scrutiny. Nottingham: National College for School Leadership.

Maguire M, Ball SJ and MacRae S (2001) 'In All Our Interests': internal marketing at Northwark Park School. British Journal of Sociology of Education 22(1): 35-50.

Maguire M, Braun A and Ball SJ (2015) 'Where you stand depends on where you sit': the social construction of policy enactments in the (English) secondary school. Discourse: Studies in the Cultural Politics of Education, 36(4): 485-499.

McGinity R and Gunter HM (2012) Living Improvement 2: A case study of a secondary school in England. Improving Schools, 15(3): 228-244.

National College (2010) Academies: research into the leadership of sponsored and converting academies. Nottingham: National College for School Leadership.

Ouston J (1988) Managing in Turbulent Times. In: Gold A and Evans J (eds.) Reflecting on School Management, London: Falmer Press, 122-133.

Pike MA (2010) Transaction and transformation at Trinity: private sponsorship, core values and Christian ethos at England's most improved academy. Oxford Review of Education 36(6): 749-765. 